\begin{tabular}{|l|l|}
\hline & $\begin{array}{l}\text { Jurnal Bimbingan dan Konseling Ar-Rahman } \\
\text { Volume 4, Nomor 2, Tahun } 2018 \\
\text { Tersedia Online: } \text { http://ojs.uniska.ac.id/index.php/BKA } \\
\text { e-ISSN 2477-6300 }\end{array}$ \\
\hline
\end{tabular}

\title{
BIMBINGAN KELOMPOK BERBASIS NILAI BUDAYA BELOM BAHADAT UNTUK MENINGKATKAN SIKAP SOPAN SANTUN PESERTA DIDIK DI MADRASAH ALIYAH NEGERI KOTA PALANGKA RAYA
}

\author{
Dony Apriatama \\ Institut Agama Islam Negeri Palangkaraya \\ apriatamadony@gmail.com
}

\begin{abstract}
ABSTRAK
Sopan santun merupakan sikap dalam tata krama yang diperlukan dalam pelaksanaan pembelajaran agar tercipta hubungan yang baik antara peserta didik dengan guru maupun sesama peserta didik. Proses pembelajaran akan sulit berjalan secara maksimal jika antara guru dengan peserta didik ataupun sesama peserta tidak menunjukkan sikap sopan santun. Berdasarkan hasil observasi di MAN Kota Palangka Raya, peserta didik tidak menunjukkan sikap sopan santun yang baik kepada guru ataupun sesama peserta didik. Tujuan penelitian ini adalah untuk meningkatkan sikap sopan santun peserta didik MAN Kota Palangka Raya melalui layanan bimbingan kelompok berbasis nilai kearifan lokal yaitu nilai budaya belom bahadat. Metode yang digunakan dalam penelitian ini adalah quasi-eksperimen. Desain penelitian yang digunakan dalam penelitian ini adalah PreExperimental Designs One-Group-Pretest-Posttest Design. Teknik pengambil sampel pada penelitian ini menggunakan teknik sampling purposive. Penelitian dilakukan dengan menysipkan nilai budaya belom bahadat ke dalam bimbingan kelompok. Hasil dari penelitian ini adalah bimbingan kelompok berbasis nilai belom bahadat terbukti efektif untuk meningkatkan sikap sopan santun peserta didik MAN Kota Palangka Raya sebesar 21\%. Konselor hendaknya selalu meningkatkan kompetensinya dalam melaksanakan bimbingan kelompok sehingga layanan yang diberikan dapat optimal dalam mengatasi masalah yang terjadi di sekolah.
\end{abstract}

Kata Kunci: bimbingan kelompok; belom bahadat; sikap sopan santun

\section{ABSTRACT}

The good attitude is a manners needed to implementation of learning in order to create a good relationship between students and teachers and fellow students. The learning process will be difficult to runsoptimally if the teacher and students or fellow students don't show good attitude. Basedon the results of observation at MAN Palangka Raya City, students didn't show good attitude to teachers or fellow students. The research was purposed to improve the good attitude of the Students at MAN Palangka Raya City through group guidance services based on the value of local wisdom, namely the cultural value of Belom Bahadat. The research design used in this research was Pre-Experimental Designs One-Group-Pretest-Posttest Design. The sampling technique in this research used purposive sampling technique.This research was carried out by incorporating the cultural value of belom bahadat into group guidance. The result showed that group guidance based on cultural value Belom Bahadat proved effective to improve the good attitude of students at MAN Palangka Raya City by $21 \%$. The counselors should always improve their competence in carrying out group guidance so that the services provided can be optimal in dealing with problems that occur in schools.

Keywords: group guidance; belom bahadat; good attitude

Dipublikasikan Oleh :

UPT Publikasi dan Pengelolaan Jurnal

Universitas Islam Kalimantan Muhammad Arsyad Al-Banjari Banjarmasin 


\section{Dony Apriatama \\ Jurnal Bimbingan dan Konseling Ar-Rahman \\ Volume 4, Nomor 2, Tahun 2018 \\ e-ISSN 2477-6300}

\section{PENDAHULUAN}

Sopan santun merupakan sikap dalam tata krama yang diperlukan dalam pelaksanaan pembelajaran agar tercipta hubungan yang baik antara peserta didik dengan guru maupun dengan sesama peserta didik. Di dalam hubungan tersebut diharapkan peserta didik dapat menghargai gurunya. Peserta didik yang memiliki sikap/perilaku norma kesopanan maka peserta didik itu sendiri akan lebih mudah dalam menyerap pembelajaran dan memperhatikan yang diberikan oleh guru. Sebaliknya tanpa adanya norma kesopanan didalam saat pembelajaran, maka transformasi ilmu dari guru ke peserta didik tidak akan bisa dapat berjalan dengan efektif.

Harapan dunia pendidikan untuk menjadikan peserta didik yang bersikap dengan baik dan berakhlak mulia tentunya bukan tanpa rintangan, seperti kasus murid yang memukul gurunya Kubu Wagiah Provinsi Kalimantan Barat. .Anggota DPRD Komisi IV Kubu Raya, KH Hanafi Khalil mengaku prihatin kasus murid sampai berani memukul gurunya sendiri. Hal ini menunjukkan betapa bobroknya etika dan akhlaq anak-anak sekarang. (dalam http://pontianak.tribunnews.com/2017/06/19/anggotadprd-prihatin-siswa-pukul-guru).

Ketika peneliti melakukan wawancara dan observasi di MAN Kota Palangka Raya, peneliti menemukan beberapa peserta didik pada saat kegiatan belajar mengajar sedang berlangsung peserta didik tidak menunjukkan sikap sopan dan santun terhadap guru yang sedang mengajar di dalam kelas. Sikap yang ditunjukkan antara lain; peserta didik sering keluar masuk kelas tanpa izin dengan guru, peserta didik sering mengejek gurunya ataupun mengejek temannya dengan ucapan yang tidak sopan, dan peserta didik menggunakan handphone pada saat pembelajaran sedang berlangsung.

Sikap di atas bertolak belakang dengan ciriciri perilaku sopan santun di sekolah menurut Supriyanti (dalam Tomahayu, 2008 : 2) antara lain: 1) Selalu tunduk dan patuh terhadap guru; 2) Melaksanakan segala hal baik ;3) Berbicara yang halus dan sopan;4) Mendoakan guru agar diberikan kesehatan dan ketabahan dalam memberikan pendidikan dan bimbingan di sekolah;5) Menjaga nama baik sekolah dan menghormati guru ; 6) Menyapa dengan ramah bila bertemu dengan guru ; 7) Menampilkan contoh tingkah laku yang baik. Contoh perwujudan sikap hormat peserta didik kepada gurunya antara lain sebagai berikut: 1) Mendengarkan nasehat guru ;2) Berbicara dengan guru harus sopan dan ramah ; 3) Memperhatikan pelajaran yang diajarkan; 4) Tidak bergurau saat pelajaran berlangsung ; 5) Menaati peraturan yang berlaku di sekolah.
Bimbingan dan konseling yang merupakan salah satu unsur penting dari sistem pendidikan. Bimbingan konseling juga memiliki peran sentral untuk mengurangi masalah-masalah sosial pada diri peserta didik dengan memberikan intervensiintervensi positif kepada peserta didik. Menurut Sukardi (2008: 64) menyatakan bahwa "layanan bimbingan kelompok memiliki tiga fungsi, yaitu 1) berfungsi informatif; 2) berfungsi pengembangan; dan 3) berfungsi preventif dan kreatif'. Berdasarkan paparan diatas, ketika guru bimbingan dan konseling akan memberikan layanan yang sifatnya preventif dan pengembangan, layanan yang dianggap tepat adalah layanan bimbingan kelompok.

Meskipun layanan bimbingan kelompok memiliki keunggulan terutama dalam menangani masalah yang berkaitan dengan bidang sosial, upaya yang telah dilakukan oleh guru bimbingan dan konseling di MAN Kota Palangka Raya belum berhasil meningkatkan sopan santun peserta didik yang terjadi dikalangan peserta didik. Informasi yang peneliti peroleh dari wawancara, materi bimbingan kelompok di MAN Kota Palangka Rayayang diberikan hanya mengulang dari tahun-tahun sebelumnya yaitu materi tentang motivasi belajar dan materi belajar secara efektif, sehingga cenderung monoton dan kurang variatif. Bimbingan kelompok dilaksanakan dengan jumlah anggota lebih dari 12 orang yaitu 1 kelas identik dengan bimbingan klasikal dan pelaksanaanya pun tidak terjadwal secara khusus. Layanan yang bersifat kelompok cenderung dilaksanakan manakala ada peserta didik yang bermasalah, kondisi tersebut menunjukkan layanan bimbingan kelompok di MAN Kota Palangka Rayatidak diperuntuhkan untuk meningkatkan sikap sopan santun, karena layanan bimbingan kelompok yang dilaksanakan lebih bersifat kasuistik.

Hurlock (2009: 257) menyatakan bahwa "perkembangan individu tidak terlepas atau dipengaruhi oleh budaya dimana individu itu berada". Peneliti berasumsi bahwa perkembangan sikap sopan santun peserta didik adalah masalah yang tidak terlepas dari etika dan budaya dalam berkelompok. Bimbingan kelompok yang dilaksanakan di MAN Kota Palangka Rayabelum menggunakan keragaman nilai budaya yang ada pada anggota kelompok sehingga solusinya adalah dengan mengangkat suatu tema yang kaya akan nilai sosial dan budaya. Untuk membantu para guru bimbingan dan konseling, peneliti akan melakukan penelitian guna menemukan suatu model yang dapat memberikan formula untuk meningkatkan sikap sopan santun.

Masyarakat di Palangka Raya memiliki suatu nilai yang mengatur cara mereka bertingkah laku yaitu nilai budaya pada nilai Belom Bahadat. "Falsafah hidup Belom Bahadat" adalah perilaku hidup yang

Dipublikasikan Oleh :

UPT Publikasi dan Pengelolaan Jurnal

Universitas Islam Kalimantan Muhammad Arsyad Al-Banjari Banjarmasin 
menjunjung tinggi kejujuran, kesetaraan, kebersamaan dan toleransi serta taat pada hukum (hukum negara, hukum adat dan hukum alam). Apabila telah mampu mnelaksanakan perilaku hidup "Belom Bahadat", maka akan teraktualisasi akan wujud "Belom Penyang Hinje Simpei" yaitu hidup berdampingan, rukun dan damai untuk kesejahteraan bersama". (Perda No. 16 Tahun 2008). Belom bahadat dijadikan bimbingan dan pengendalian moral masyarakat suku dayak ngaju.

Untuk mencapai tujuan tersebut, maka salah satu program pendidikan di sekolah yang ikut menentukan keberhasilan bagi peserta didik agar peserta didik dapat memiliki pemahaman norma kesopanan dan menjujung tinggi nilai adab dalam bertingkah laku sebagaimana mestinya yaitu dengan penggunaan layanan bimbingan kelompok berbasis nilai budaya Belom bahadat .

Dengan keterikatan bimbingan kelompok berbasis nilai budaya Belom bahadat diharapkan peserta didik dapat meningkatkan pemahamannya, menerapkan, menggali, dan melestarikan nilai nilai budaya yang ada dikalimantan tengah salah satunya nilai nilai budaya Belom Bahadat.

\section{METODE}

Metode yang digunakan dalam penelitian ini adalah metode eksperimen yang bertujuan untuk mencari pengaruh mencari pengaruh perlakuan tertentu (treatment) terhadap variabel lain dalam kondisi yang dikendalikan. kelompok terhamemperoleh informasi yang dapat diperoleh (Sugiyono, 2015: 73). Metode ini sesuai digunakan pada penelitian ini yang menginginkan informasi pengaruh bimbingan kelompok berbasis nilai budaya belom bahadat untuk meningkatkan sikap sopan santun peserta didik kelas kelas X MAN Kota Palangka Raya.

Desain penelitian yang digunakan dalam penelitian ini adalah PreExperimental Designs OneGroup-Pretest-Posttest Design yaitu desain penelitian yang masih terdapat variabel luar yang ikut berpengaruh terhadap variabel dependen. Jadi hasil eksperimen yang merupakan variabel dependen itu bukan semata-mata dipengaruhi oleh variabel independen. Hal ini dapat terjadi, karena tidak adanya variabel kontrol dan sampel tidak dipilih secara random (Sugiyono, 2015:74). One-Group-PretestPosttest Design yaitu membandingkan keadaan anatara sebelum dan sesudah di beri perlakuan terhadap subjek tertentu. Dengan demikian hasil perlakuan dapat diketahui lebih akurat, karena dapat membandingkan dengan keadaan sebelum diberi perlakuan. Desain ini dapat digambarkan seperti berikut:

\begin{tabular}{lll}
\hline O1 & X & O2 \\
\hline
\end{tabular}

\section{Dipublikasikan Oleh :}

UPT Publikasi dan Pengelolaan Jurnal

Universitas Islam Kalimantan Muhammad Arsyad Al-Banjari Banjarmasin
Keterangan :

$\mathrm{O} 1=$ nilai pretest (sebelum diberi perlakuan)

$\mathrm{O} 2=$ nilai posttest (setelah diberi perlakuan)

$\mathrm{X}=$ eksperimen

Dalam desain ini diberikan kepada kelompok tunggal dengan diberikan terlebih dahulu pretest (tes awal) dan setelah diberi treatment sampel diberi posttest (tes akhir). Desain penelitian One Group pretest and post-test dilakukan dengan cara memberikan pretest (O1) kepada peserta didik kelas X, untuk mengetahui kondisi awal pemahaman peserta didik sebelum mendapatkan perlakuan. Selanjutnya sampel penelitian diberikan perlakuan berupa bimbingan kelompok berbasis nilai budaya belom bahadat. Perbedaan antara tes awal dan tes akhir (O1dan O2) yakni $\mathrm{O} 1<\mathrm{O} 2$ diasumsikan sebagai adanya pengaruh daritreatment $(\mathrm{X})$. Desain ini dilakukan sesuai dengan tujuan yang hendak dicapai yaitu ingin mengetahui efektivitas bimbingan kelompok berbasis nilai budaya belom bahadat dalam meningkatkan sikap sopan santun.

\section{1) Populasi dan Sampel Penelitian.}

\section{a) Populasi Penelitian}

Menurut Arikunto (2013 : 173) menyatakan bahwa "populasi adalah keseluruhan objek peneitian". Mengingat penelitian ini untuk melihat apakah ada perbedaan pemahaman tentang sopan santun peserta didik ditinjau dari pemberian layanan bimbingan kelompok berbasis budaya Belom Bahadat, maka yang akan menjadi populasi dalam penelitian ini adalah peserta didik kelas X yang berjumlah 331 orang.

Tabel 3.1 Populasi Penelitian

\begin{tabular}{clccc}
\hline \multirow{2}{*}{ Kelas } & \multirow{2}{*}{ Jurusan } & \multicolumn{3}{c}{ Jumlah } \\
\cline { 3 - 5 } X & MIPA 1 & 9 & P & Total \\
\hline & MIPA 2 & 11 & 19 & 29 \\
& MIPA 3 & 10 & 23 & 33 \\
& MIPA 4 & 12 & 20 & 32 \\
& MIPA 5 & 11 & 13 & 24 \\
& IIS 1 & 17 & 21 & 38 \\
& IIS 2 & 21 & 17 & 38 \\
& Bahasa & 11 & 25 & 36 \\
& Agama 1 & 17 & 19 & 36 \\
& Agama 2 & 17 & 18 & 35 \\
\hline & 136 & 195 & 331 \\
\hline
\end{tabular}

Sumber data : Tata Usaha MAN Kota Palangka Raya

\section{b) Sampel Penelitian}

Menurut Hadi (dalam Narbuko dan Achmadi, 2013 : 107 ) menyatakan bahwa sampel adalah sebagian dari individu yang diselidiki dari keseluruhan individu penelitian". Adapun teknik yang peneliti gunakan ini disebut juga dengan teknik sampling purposive yaitu penentuan sampel dengan pertimbangan tertentu. Layanan bimbingan kelompok 
menggunakan dinamika kelompok dalam pelaksanaannya, maka pengambilan sampel dilakukan dengan pertimbangan tingkat sikap sopan santun yang heterogen. rincian sampel sebagai berikut.

Tabel 3.2 Kelas Sampel

\begin{tabular}{lc}
\hline \multicolumn{1}{c}{ Tingkat Sopan santun } & $\begin{array}{c}\text { Peserta } \\
\text { didik }\end{array}$ \\
\hline Sangat Tinggi & 2 \\
Tinggi & 2 \\
Rendah & 2 \\
Sangat Rendah & 2 \\
\hline Jumlah & 8 \\
\hline
\end{tabular}

\section{2) Teknik Pengumpulan Data dan Instrumen} Penelitian

\section{a) Wawancara}

Penelitian ini menggunakan teknik wawancara yang bertujuan untuk menggali informasi secara tatap muka dengan narasumber (konselor) tentang pelaksanaan bimbingan kelompok disekolah. Wawancara yang digunakan pada penelitian ini menggunakan wawancara terstruktur yaitu peneliti sudah menyiapkan pertanyaan-pertanyaan yang hendak di tanyakan kepada narasumber. Berikut kisikisi wawancaranya, antara lain:

\section{b) Observasi}

Teknik observasi pada penelitian ini bertujuan untuk mengamati sikap sopan santun peserta didik. Observasi yang dilakukan dengan mengamati cara berperilaku, respon, peserta didik ketika berhubungan dengan sesama, guru, konselor, staff sekolah ataupun sesama murid.

\section{c) Angket}

Kuesioner merupakan metode pengumpulan data yang dilakukan dengan cara memberi seperangkat pertanyaan atau pernyataan tertulis kepada responden untuk dijawab. Kuesioner merupakan metode pengumpulan data yang lebih efisien bila peneliti telah mengetahui dengan pasti variabel yag akan diukur dan tahu apa yang diharapkan dari responden. Selain itu kuesioner juga cocok digunakan bila jumlah responden cukup besar dan tersebar di wilayah yang luas. Penelitian ini menggunakan angket Skala Likert umumnya digunakan untuk mengukur sikap atau respons seseorang terhadap suatu objek. Pengungkapan sikap dengan menggunakan skala Likert sangat popular di kalangan para ahli psikologi sosial dan para peneliti. Hal ini dikarenakan selain praktis, skala Likert yang dirancang dengan baik pada umumnya memiliki reliabilitas yang memuaskan. Skala Likert berwujud kumpulan pertanyaanpertanyaan sikap yang ditulis, disusun dan dianalisis sedemikian rupa sehingga respons seseorang terhadap pertanyaan tersebut dapat diberikan angka (skor) dan kemudian dapat diinterpretasikan.

Kriteria pemberian skor meliputi 4 item yang positif, jawaban SS mendapat nilai 4, jawaban S mendapat nilai 3, jawaban TS mendapat nilai 2 dan jawaban STS mendapat nilai 1. Sedangkan kriteria pemberian skor untuk item yang negatif, jawaban SS mendapat nilai 1, jawaban $S$ mendapat nilai 2, jawaban TS mendapat nilai 3 dan jawaban STS mendapat nilai 4.

Tabel 3.5 Skala Likert Kategori Jawaban Instrumen Penelitian

\begin{tabular}{clcc}
\hline \multirow{2}{*}{ No } & \multicolumn{2}{c}{ Pernyataan Positif } & \multicolumn{2}{c}{ Nilai } \\
\cline { 2 - 4 } & Jawaban & 4 & 1 \\
\hline 1 & SS (sangat sesuai) & 3 & 2 \\
\hline 2 & S (Sesuai) & 2 & 3 \\
\hline 3 & TS (Tidak Sesuai) & 1 & 4 \\
\hline 4 & STS (Sangat Tidak Sesuai) &
\end{tabular}

\section{3) Instrumen Pengumpulan Data}

Menurut Sugiyono (2015:199) “Angket merupakan tehnik pengumpulan data yang dilakukan dengan cara memberi seperangkat pertanyaan atau pernyataan tertulis kepada responden untuk dijawab". Menurut Arikunto (2010 : 209) prosedur yang ditempuh adalah perencanaan, penulisan butir soal, penyuntingan, uji coba, penganalisaan hasil, dan mengadakan revisi. Sedangkan dalam penelitian ini, langkah-langkah yang ditempuh oleh peneliti dalam pengadaan instrumen antara lain: membuat kisi-kisi instrumen, lalu dikonsultasikan dengan ahli, hasil konsultasi direvisi jika perlu, instrumen yang telah direvisi siap disebarkan.

\section{4) Teknik Analisis Data}

Teknik analisa data merupakan suatu langkah yang paling menentukan dari suatu penelitian, karena analisa data berfungsi untuk menyimpulkan hasil penelitian. Analisis data dapat dilakukan melalui tahap berikut ini:

\section{a. Tahap editing}

Angket yang telah diisi oleh responden kemudian dikumpulkan dan dilakukan editing untuk mengecek kebenaran atau kelengkapan data. Semua angket yang telah diisi responden data sudah lengkap dan pengisian angket sesuai dengan petunjuk pengisian angket sesuai dengan petunjuk pengisian

Dipublikasikan Oleh :

UPT Publikasi dan Pengelolaan Jurnal

Universitas Islam Kalimantan Muhammad Arsyad Al-Banjari Banjarmasin 
angket. Sehingga peneliti tidak perlu melakukan perbaikan.

\section{b. Skoring (penilaian)}

Pada penelitian ini sering dilakukan berdasarkan hasil dari setiap jawaban responden sesuai dengan definisioperasional penelitian. Data yang diperoleh dari hasil penyebaran, selanjutnya dianalisis. Analisis skor pernyataan yang digunakan dalam pada penelitian ini menggunakan skala likert. Model skala likert yaitu model skala yang menggunakan pembagian area dalam suatu kontinum tertentu yang memiliki lima pilihan jawaban. Setiap pernyataan mempunyai lima pilihan jawaban yaitu SS, S, KS, TS, dan STS.

Selanjutnya menjumlahkan skor yang diperoleh oleh masing-masing peserta didik. Untuk mengetahui perbedaan pemahaman peserta didik tentang sopan santun digunakan kategorisasi dari Hadi (2004: 150), yakni:

- $\quad$ Mean ideal $+1,5$ SD ke atas = Sangat Tinggi

- $\quad$ Mean ideal sampai dengan mean ideal $+1,5$ $\mathrm{SD}=$ Tinggi

- Mean ideal- 1, 5 SD sampai dengan mean ideal $=$ Rendah

- Mean ideal- 1, 5 SD ke bawah = Sangat Rendah

Selanjutnya ke empat kategorisasi tersebut akan disusun kemudian dianalisis secara deskriptif kuantitatif. Selanjutnya guna pengujian hipotesis digunakan analisis data kuantitatif dengan statistik non-parametris, yaitu menggunakan melalui uji-t karena penelitian ini bertujuan untuk mencari perbedaan pemahaman tentang sopan santun antara yang diberi layanan bimbingan kelompok dan yang tidak diberikan layanan bimbingan kelompok.

c. Entry (memasukkan data)

Tahap terakhir dalam penelitian ini yaitu pemrosesan data, yang dilakukan oleh peneliti ke dalam memasukan data dari angket ke dalam paket program komputer.

\section{d. Tabulasi data}

Tabulasi adalah proses menempatkan data dalam bentuk tabel dengan cara membuat tabel yang berisikan data sesuai dengan kebutuhan analisis. Tabel yang dibuat sebaiknya mampu meringkas semua data yang akan di analisis.

\section{e. Processing}

Setelah diedit akan diberi kode, kemudian data diproses menggunakan program program SPSS 23.00 melalui Uji Wilcoxon. Untuk pengujian hipotesis digunakan analisis data kuantitatif dengan teknik statistik non-parametris, yaitu menggunakan Tes Ranking Bertanda (Wilcoxon Test). Wilcoxon test digunakan untuk menguji signifikasi hipotesis komparatif 2 (dua) sampel yang berkorelasi bila datanya berbentuk ordinal dan atau berjenjang
(Sugiyono, 2011: 205). Tes Wilcoxon dicari dengan cara mencari perbedaan antara skor kelompok evaluasi awal dengan skor kelompok evaluasi akhir. Selanjutnya beda antara skor evaluasi awal dan evaluasi akhir diberi rangking (jenjang).

Hipotesis tindakan pada penelitian ini adalah model bimbingan kelompok berbasis nilai budaya belom bahadat untuk meningkatkan sikap sopan santun peserta didik kelas X di MAN Kota Palangka Raya. Hipotesis tersebut adalah hipotesis asli/alternatif (Ha). Untuk pengujian Ha diubah menjadi hipotesi nol (Ho), model bimbingan kelompok berbasis nilai budaya belom bahadat untuk meningkatkan sikap sopan santun peserta didik kelas X di MAN Kota Palangka Raya. Dalam pembuktian Ha dan Ho akan diterima atau ditolak maka jumlah rangking/jenjang yang kecil kita bandingkan dengan tabel harga-harga kritis dalam tes Wilcoxon dengan taraf kesalahan 5\%.

- $\quad$ Ho diterima jika $\mathrm{T}$ (jenjang terkecil) $>$ dari T tabel Wilcoxon, maka Ha ditolak.

- Ho ditolak jika T (jenjang terkecil) < dari T tabel Wilcoxon, maka Ha diterima.

\section{HASIL DAN PEMBAHASAN \\ 1. Paparan Data Penelitian \\ 2.1. Hasil wawancara}

Untuk mendapatkan gambaran mengenai kondisi objektif layanan bimbingan kelompok, peneliti mengadakan wawancara dengan 2 (dua) orang konselor di MAN Kota Palangka Raya. Berikut hasil wawancaranya:

\section{a) Perencanaan Bimbingan Kelompok}

Layanan bimbingan kelompok di MAN Kota Palangka Raya belum terencana secara matang. Hal tersebut terlihat dalam pemberian yang sifatnya sifatnya insindental karena di MAN Kota Palangka Raya konselor tidak mempunyai jadwal jam masuk kelas yang berarti bahwa bimbingan kelompok hanya diberikan untuk mengisi jam kosong ketika guru mata pelajaran tidak hadir atau absen.

Konselor melakukan koordinasi dengan wali kelas dan guru mata pelajaran untuk mengetahui need assesment peserta didik. Need asessment dilakukan melalui observasi secara langsung dan daftar cek masalah. Melalui hasil need asessment yang di dapatkan, di analisis aspek mana yang menjadi prioritas kebutuhan peserta didik. Perekrutan peserta didik untuk di jadikan anggota kelompok tidak dilakukan. Bimbingan kelompok diberikan konselor dengan masuk ke kelas kosong yang berarti seluruh peserta didik di kelas merupakan anggota kelompok. Hal tersebut identik dengan pemberian layanan penguasan konten (bimbingan klasikal). Materi bimbingan kelompok yang di laksanakan tidak di dominasi oleh bidang bimbingan pribadi misalkan masalah ketidakhadiran atau bolos saat jam pelajaran 
sekolah sedangkan materi berkaitan dengan masalah sosial tidak pernah diberikan. Kompetensi untuk menjadi pemimpin kelompok dalam bimbingan kelompok harus dilakukan oleh konselor yang merupakan lulusan S-1 BK yang dianggap memahami teori dan praktik bimbingan konseling secara komprehensif.

\section{b) Pelaksanaan Kegiatan bimbingan kelompok}

Dalam persiapan pelaksanaan kegiatan bimbingan kelompok dilakukan dengan menyiapkan materi serta waktu dan tempat dengan berkoordinasi dengan guru mata pelajaran. Pemberian layanan bimbingan kelompok tidak terjadwal (menunggu kelas kosong), tetapi biasanya pemberian layanan diberikan minimal 2 kali dalam 1 (satu) semester.

Tujuan yang ingin dicapai dalam pelaksanaan bimbingan kelompok MAN Kota Palangka Raya bertujuan unttuk membantu peserta didik menyelesaikan masalah baik yang sedang di alami maupun yang sifatnya preventif serta mengembangkan potensi-potensi, bakat dan minat peserta didik.

Untuk melihat keterlaksanaan secara rinci, peneliti mengumpulkan informasi mengenai kegiatankegiatan yang dilakukan dalam setiap tahap-tahap bimbingan kelompok yang dilaksanakan di MAN Kota Palangka Raya. Pada tahap awal konselor dan anggota kelompok saling menyapa dengan memberi salam, tahap basa basi untuk menghilangkan ketegangan, menjelaskan tujuan pemberian layanan bimbingan kelompok, menjelas asas-asas dan aturan untuk terlaksananya bimbingan kelompok yang optimal dan kontrak waktu. Pada tahap peralihan pemimpin kelompok menumbuhkan suasana yang dapat membawa para anggota dalam kegiatan sesungguhnya. Pada tahap ini konselor menegaskan kembali dan memastikan persetujuan anggota kelompok mengenai asas dan ketentuan-ketentuan yang harus di taati. Pada tahap kegiatan, pemimpin kelompok mengajak para anggota fokus pada diskusi multi arah. Untuk mendukung materi yang di sampaikan dan menggali antusiasme para anggota pemimpin kelompok menyisipkan permainan dalam tahap ini. Dalam pemilihan topik, biasanya untuk menggali antusiasme peserta didik binaan dalam layanan, topik yang dipilih konselor adalah topik tugas dimana materi yang akan di bahas sudah di tentukan oleh pemimpin kelompok yang di dapatkan dari hasil analisis need assesment.

Dalam bidang sosial, konselor tidak pernah mengadakan bimbingan kelompok dengan tema-tema sosial, kebanyakan materi yang selama di berikan dalam layanan bimbingan kelompok dengan tematema kedisiplinan dan tata tertib. Materi tentang sopan santun tidak pernah di angkat dalam bimbingan kelompok. Pada tahap pengakhiran, pemimpin kelompok mulai melakukan memberikan pertanyaanpertanyaan untuk mengukur tingkat partisipasi anggota dalam kelompok.

\section{c) Evaluasi dan Tindak Lanjut}

Evaluasi yang dilakukan oleh konselor MAN Kota Palangka Raya terhadap layanan bimbingan kelompok yang telah dilaksanakan dengan cara berkoordinasi dengan wali kelas untuk mengamati perubahan perilaku peserta didik. Hasil dari evaluasi di analisis sebagai bahan tindak lanjut apakah layanan bimbingan kelompok sudah cukup baik atau sesuai dengan tujuan yang ingin dicapai. Apabila masih ada individu yang belum menunjukkan perubahan perilaku setelah diberikan layanan bimbingan kelompok, maka di lakukan konseling individu sebagai bentuk follow up.

\section{d) Faktor Pendukung dan Penghambat}

Faktor yang mendukung kegiatan bimbingan kelompok di MAN Kota Palangka Raya adalah adanya partisipasi dari unsur -unsur lain yang ada disekolah antara lain guru mata pelajaran, wali kelas, tata usaha dan kepala sekolah. Sedangkan faktor yang meghambat adalah kurangnya sarana prasarana untuk melaksanakan bimbingan kelompok seperti ruangan, waktu yang tersedia hanya mengandalkan jam pelajaran kosong, LCD serta sumber biaya yang minim.

Berdasarkan gambaran mengenai kondisi faktual pelaksanaan bimbingan kelompok di MAN Kota Palangka Raya yang di uraikan di atas, maka peneliti menyimpulkan bahwa layanan bimbingan kelompok dilaksanakan oleh para konselor dimana layanan belum terencana dalam program. Namun karena terikat pada ketersediaan waktu, pelaksanaannya tidak bisa maksimal. Konselor hanya mengisi jam pelajaran kosong.

Upaya konselor untuk mengatasi masalah yang berkaitan dengan kehidupan sosial kurang diperhatikan. Hal ini terlihat dalam pemberian layanan bimbingan kelompok yang lebih berfokus pada masalah disiplin dan tata aturan di sekolah. Upaya konselor untuk mengatasi masalah yang berkaitan dengan kehidupan sosial harus di berikan mengingat kondisi beberapa peserta didik di MAN Kota Palangka Raya yang menunjukkan kurangnya sopan santun terhadap sesama ataupun guru. Berdasarkan uraian di atas, peneliti menyimpulkan perlu adanya model layanan bimbingan kelompok yang diinovasi dengan nilai kehidupan sosial yang terdapat dalam kebudayaan lokal yaitu budaya belom bahadat.

\subsection{Hasil Observasi}

Observasi bertujuan untuk melihat sikap sopan santun peserta didik di lingkungan MAN kota Palangka Raya. Observasi dilakukan di lingkungan MAN Kota Palangka Raya dengan melihat sikap sopan santun peserta didik dengan sesama maupun 
dengan guru di sekolah. Peneliti mengamati beberapa peserta didik tidakbertegur sapa dengan gurunya jika berpas-pasan. Peserta didik tidak menyapa dan menunjukkan wajah acuh tak acuh. Peneliti mencoba melakukan konfirmasi terhadap beberapa peserta didik tersebut. Alasan mereka tidak menyapa karena mereka tidak mengenal gurunya dan guru tersebut tidak pernah mengajar dikelas mereka.

Sedangkan hubungan antar sesama pesera didik, observer melihat beberapa peserta didik yang saling mengolok-ngolok nama orangtua, tidak mengucapkan salam ketika masuk ke kelas, dan ketika diskusi kelompok terlihat ada peserta didik yang tidak menghargai pendapat temannya dengan menentang pendapatnya dengan keras terkesan ingin menjatuhkan.

Dari hasil observasi yang di dapatkan menunjukkan beberapa peserta didik tidak menunjukkan sikap sopan santun kepada gurunya ataupun dengan sesama peserta didik. Perilaku yang ditunjukkan seperti tidak bertegur sapa dengan guru ketika berpas-pasan di lingkungan sekolah, tidak mengucapkan salam ketika masuk ke kelas, mengolok-olok sesama peserta didik,dan tidak menghargai pendapat sesama peserta didik. Peneliti menyimpulan hal itu bisa terjadi karena kurangnya kurangnya pemahaman sikap sopan santun yang ada di peserta didik terlihat dari hasil wawancara kepada peserta didik yang menyatakan bahwa tidak menyapa karena mereka tidak mengenal gurunya dan guru tersebut tidak pernah mengajar dikelas mereka. Mereka hanya menegur guru yang pernah mengajar saja karena kenal.

\subsection{Hasil Angket sikap sopan santun peserta didik di MAN Kota Palangka Raya}

Gambaran tentang kondisi sikap sopan santun peserta didik MAN Kota Palangka Raya diperoleh dari hasil penyebaran skala Sopan Santun di kelas X MAN Kota Palangka Raya yang berjumlah 209 peserta didik yang terbagi menjadi 9 kelas. Kemudian, peneliti memberikan instrumen berupa skala Sopan Santun kepada masing-masing orang. Instrumen terdiri dari dari 48 item pernyataan yang digunakan untuk mengukur tingkat sikap sopan santun peserta didik kelas X di MAN Kota Palangka Raya. Semua peserta didik mengerjakannya sesuai dengan petunjuk yang dijelaskan oleh peneliti. Perolehan skor gambaran sikap sopan santun peserta didik, sebagaimana terlihat dalam tabel berikut.

Tabel 4.4 Gambaran Tingkat Sikap sopan santun peserta didik Kelas X MAN Kota Palangka Raya

\begin{tabular}{lll}
\hline KATEGORI & F & \% \\
\hline Sangat rendah & 11 & 5 \\
Rendah & 18 & 9 \\
Tinggi & 180 & 86 \\
Sangat tinggi & 0 & 0 \\
JUMLAH & $\mathbf{2 0 9}$ & $\mathbf{1 0 0}$ \\
\hline
\end{tabular}

Dari tabel 4.4. menunjukkan bahwa jumlah peserta didik memiliki Sopan Santun yang sangat rendah adalah 11 orang (5\%), yang memiliki Sopan Santun yang sedang 18 orang $(9 \%)$, yang memiliki Sopan Santun yang tinggi adalah 180 orang $(86 \%)$.

Melihat data pada tabel 4.4 menunjukkan bahwa perlu adanya upaya bantuan bagi peserta didik agar mereka dapat mengatasi masalah dalam kehidupan sosial dengan baik. Pelaksanaan layanan bimbingan kelompok saja tidak cukup untuk mengatasi masalah Sopan Santun yang rendah. Konselor membutuhkan sebuah model pelayanan bimbingan kelompok yang tepat dan efektif untuk dapat membantu mengurangi atau bahkan mengatasi sikap sopan santun peserta didik yang rendah.

Oleh karena itu, agar layanan bimbingan kelompok di MAN Kota Palangka Raya dapat membantu peserta didik meningkatkan sikap Sopan Santunnya maka model bimbingan kelompok berbasis nilai budaya belom bahadat dibuat sebagai inovasi untuk masalah yang berkaitan dengan lunturnya nilai kesopanan. Dengan demikian, diharapkan dengan tersusunnya model bimbingan kelompok berbasis nilai budaya belom bahadat dapat membantu konselor di MAN Kota Palangka Raya bahkan sekolah-sekolah lainnya di Palangka Raya dalam melaksanakan bimbingan kelompok untuk meningkatkan sikap sopan santun peserta didik.

Berdasarkan hasil studi pendahuluan tentang tingkat sikap sopan santun peserta didik kelas $\mathrm{X}$ di MAN Kota Palangka Raya, guna kepentingan penelitian maka peneliti mengambil 8 peserta didik secara purposive sampling sebagai anggota kelompok yang nantinya akan diberi layanan bimbingan kelompok berbasis nilai budaya belom bahadat. Ke-8 anggota kelompok tersebut bersifat heterogen untuk tingkat Sopan Santunnya, yakni 1 peserta didik dengan Sopan Santun sangat rendah, 6 peserta didik dengan Sopan Santun rendah, 1 peserta didik dengan Sopan Santun tinggi. Berikut data dari ke- 8 anggota bimbingan kelompok: 
Tabel 4.5 Profil (Awal) Anggota Kelompok

\begin{tabular}{|c|c|c|c|c|}
\hline No. & Nama & $\begin{array}{l}\text { Evaluasi } \\
\text { Awal }\end{array}$ & Kat. & Gambaran Sopan Santun \\
\hline 1 & KA & 120 & $\mathrm{~T}$ & $\begin{array}{l}\text { Hoby bernyanyi, percaya diri, mempunyai banyak teman, aktif dalam } \\
\text { kegiatan pramuka, mampu berkomunikasi secara lugas }\end{array}$ \\
\hline 2 & RA & 86 & $\mathrm{R}$ & $\begin{array}{l}\text { Acuh terhadap sekitar, kurang percaya dengan teman, selalu } \\
\text { menyendiri, aktif dalam kegiatan basket }\end{array}$ \\
\hline 3 & SSP & 75 & SR & $\begin{array}{l}\text { Periang, kurang bisa mengintrol emosi, aktif di kelas, mudah terbawa } \\
\text { suasana, tidak mampu menahan untuk berbicara, suka mengejek. }\end{array}$ \\
\hline 4 & FR & 85 & $\mathrm{R}$ & $\begin{array}{l}\text { Pendiam, Takut berbicara dengan orang yang tidak di kenal, kurang } \\
\text { percaya diri, }\end{array}$ \\
\hline 5 & IF & 90 & $\mathrm{R}$ & Tidak tegas, suka ragu-ragu, memiliki banyak teman di luar kelas. \\
\hline 6 & $\mathrm{~S}$ & 87 & $\mathrm{R}$ & $\begin{array}{l}\text { Pendiam, kurang percaya diri, takut berbicara dengan orang yang tidak } \\
\text { di kenal, kurang aktif di kelas, hoby bermain gitar, orang tua tinggal di } \\
\text { desa dan dipalangkaraya tinggal dengan paman. }\end{array}$ \\
\hline 7 & $\mathrm{PN}$ & 114 & $\mathrm{R}$ & Pendiam, ramah, kurang percaya diri \\
\hline 8 & ASA & 91 & $\mathrm{R}$ & Pendiam, kurang percaya diri, takut berbicara di depan, penakut. \\
\hline
\end{tabular}

2.4. Model Bimbingan Kelompok Berbasis Nilai Budaya Belom bahadat Untuk Meningkat Sikap Sopan Santun

Berdasarkan hasil kajian empiris pada studi lapangan bisa diasumsikan beberapa hasil, antara lain:

1. Bimbingan kelompok sudah dilaksanakan di MAN Kota Palangka Raya akan tetapi hasilnya belum efektif. Ada beberapa hambatan yang menjadi penyebab belum efektifnya ketercapaian hasil dari pelaksanaan layanan bimbingan kelompok di MAN Kota Palangka Raya, baik dari segi konselor sebagai penyelenggara layanan dan pemimpin kelompok, peserta didik sebagai anggota kelompok, waktu dan tujuan pelaksanaan layanan, jenis materi/topik yang menjadi bahasan, biaya, wali kelas dan guru mata pelajaran yang menjadi kolaborator bagi guru bimbingan dan konseling.

2. Pelaksanaan bimbingan kelompok di MAN Kota Palangka Raya belum menggunakan pendekatan atau basis tertentu dalam layanan bimbingan kelompok sehingga efektivitas layanan tidak tercapai secara optimal.

3. Topik tentang nilai kesopanan belum pernah dijadikan bahasan dalam layanan bimbingan kelompok di MAN Kota Palangka Raya, karena guru bimbingan dan konseling tidak memiliki program khusus tentang topik tersebut.

4. Tingkat sikap sopan santun peserta didik yang di peroleh pada saat studi pendahuluan dan yang di tunjukan dengan skala sopan santun (pre-tes) menunjukkan perlu adanya upaya bantuan bagi peserta didik untuk dapat mengurangi sopan santun.

Berdasarkan data di atas maka peneliti kemudian menimbang serta memutuskan bahwa model bimbingan kelompok berbasis nilai budaya belom bahadat akan dikembangkan terdiri dari 6 komponen utama, sebagai berikut :

\section{Rasional}

Rasional menjelaskan secara rinci tentang konsep pemikiran dalam mengembangkan model bimbingan kelompok berbasis nilai budaya belom bahadat dengan penjabaran secara singkat dan jelas akan gambaran pelaksanaan yang disesuaikan dengan target pencapaian kegiatan bimbingan kelompok yaitu meningkatkan sikap sopan santun peserta didik. Dalam rasional dikemukakan nilai yang terkandung dalam budaya belom bahadat antara lain takwa kepada tuhan, persamaan derajat, tenggang rasa, tidak semena-mena, menjunjung tinggi kemanusiaan, persatuan dan kesatuan, rela berkorban, cinta tanah air, musyawarah dan mufakat, rasa kekeluargaan, nurani yang luhur, menjunjung tinggi kebenaran, bertanggung jawab, menjunjung tinggi peri keadilan, gotong royong, menjaga keseimbangan hak dan kewajiban, menghormati hak-hak orang lain, sifat suka bekerja keras, menghargai karya orang lain, sifat keteladanan, semangat pengasih, ramah tamah, rasa saling hormat, sifat keterampilan diujung jari dan diunjung lidah, menjaga keseimbangan lingkungan dan lain-lain.

\section{Visi dan Misi}

Dalam hal pencapai tujuan penelitian dalam rangka meningkatkan sikap sopan santun peserta didik maka di perlukan suatu perencanaan dan tindakan nyata untuk dapat mewujudkannya. Secara umum dapat dikatakan bahwa visi dan misi adalah suatu konsep perencanaan yang di sertai dengan tindakan sesuai dengan apa yang di rencanakan untuk mencapai suatu tujuan yang berdasarkan nilai budaya belom bahadat dan juga aspek-aspek yang akan di capai pada sikap sopan santun peserta didik. 


\section{Tujuan}

Yaitu tujuan yang ingin di capai dari pengembangan model bimbingan kelompok berbasis nilai budaya belom bahadat. Tujuan ini di bagi menjadi 2, yakni tujuan umum dan tujuan khusus yang keduanya terfokus pada meningkatkan sikap sopan santun peserta didik disesuaikan dengan indikator serta aspek-aspek nilai yang terkandung dalam budaya belom bahadat.

\section{Isi Bimbingan dan Konseling}

Meliputi ranah bidang bimbingan yang dapat diintervensi oleh pelaksanaan kegiatan bimbingan kelompok berbasis nilai budaya belom bahadat untuk meningkatkan sikap sopan santun peserta didik. Ranah bimbingan terdiri dari ranah bidang bimbingan pribadi, bidang bimbingan belajar, dan bidang bimbingan sosial

\section{Pendukung sistem}

Dimaksudkan dalam rangka menyukseskan kegiatan bimbingan dan kelompok dan adanya keterjalinan kerjasama serta dukungan penuh dari stake holder yang ada disekolah.

\section{Bimbingan kelompok berbasis nilai budaya}

\section{belom bahadat}

Termasuk didalamnya tahapan-tahapan dalam kelompok yang akan dilalui dan dilaksanakan dalam kelompok beserta susunan materi yang digunakan dengan maksud agar garis besar kegiatan bimbingan kelompok berisikan materi yang tidak keluar dari tujuan awal yang telah ditetapkan yaitu meningkatkan sikap sopan santun peserta didik.

\subsection{Persiapan Model}

1. Mengatur waktu pelaksanaan layanan bimbingan kelompok berbasis nilai budaya belom bahadat bersama guru bimbingan dan konseling serta peserta didik yang menjadi anggota kelompok. Berdasarkan kesepakatan bersama kegiatan akan dilaksanakan pada hari Senin dan kamis (1 minggu 2 kali).

2. Mempersiapkan sarana dan prasarana yang diperlukan dalam pelaksanaan layanan bimbingan kelompok berbasis nilai budaya belom bahadat.

3. Mempersiapkan kelengkapan administrasi layanan bimbingan kelompok berbasis nilai budaya belom bahadat, seperti daftar hadir, satuan layanan, dan materi.

4. Menyiapkan alat evaluasi berupa lembar laiseg dan skala sikap sopan santun.

\subsection{Pelaksanaan Model}

Basis yang digunakan dalam pengembangan model adalah nilai budaya belom bahadat dengan target intervensinya untuk meningkatkan sikap sopan santun peserta didik. Oleh karena itu materi, perlakuan, serta teknik yang digunakan dalam pelaksanaan uji lapangan harus bisa memunculkan nilai budaya belom bahadat dari konselor dan anggota kelompok untuk meningkatkan sikap sopan santun secara optimal. Berikut sajian tabel dari indikator yang akan ditingkatkan beserta perlakuan yang diberikan:

\section{7 . \\ Uji Efektivitas Model Bimbingan}

Secara kuantitatif menurunnya tingkat sopan santun peserta didik bisa dilihat dari perbandingan nilai evaluasi awal dan evaluasi akhir yang diperoleh masing-masing anggota kelompok. Tabel 4.7 menunjukkan rincian perolehan skor evaluasi awal dan evaluasi akhir anggota kelompok pada semua indikator.

Berdasarkan tabel 4.7 terlihat bahwasanya sopan santun pada semua peserta didik yang menjadi anggota kelompok mengalami peningkatan (nilai post test lebih tinggi dari nilai pretest). Ketercapaian hasil tersebut karena layanan bimbingan kelompok berbasis nilai belom bahadat dilaksanakan secara profesional sesuai dengan prosedur yang telah direncanakan, walaupun terjadi beberapa hambatan saat kegiatan berlangsung. Faktor-faktor yang mendukung penurunan sopan santun peserta didik antara lain:

1. Pemimpin kelompok sebagai motivator mampu mengoptimalkan nilai budaya belom bahadat, tidak hanya pada diri sendiri tapi juga pada anggota kelompok dalam setiap tahapan layanan bimbingan kelompok. Artinya nilainilai budaya belom bahadat terintegrasi secara optimal pada setiap tahapan layanan.

2. Materi yang menjadi topik bahasan, yakni tentang nilai dari budaya belom bahadat, sesuai dengan tingkat kebutuhan peserta didik pada umumnya dan anggota kelompok pada khususnya.

3. Konselor sebagai perencana kegiatan mampu memberikan perlakuan yang tepat sesuai dengan topik bahasan dan karakteristik peserta didik yang menjadi anggota kelompok, yakni usia remaja. Perlakuan yang diberikan tersebut dapat menstimulus anggota kelompok untuk mengoptimalkan nilai dari budaya belom bahadat, sehingga mereka secara aktif menunjukan peranannya dalam menciptakan dinamika kelompok.

4. Anggota kelompok mau dan mampu bersikap terbuka serta aktif, pada saat pelaksanaan layanan bimbingan kelompok berbasis nilai budaya belom bahadat.

5. Pembentukan kelompok secara heterogen mampu menumbuhkan dinamika kelompok dengan baik sehingga secara otomatis mampu menstimulus anggota kelompok yang awalnya pasif untuk lebih berperan aktif dalam kegiatan kelompok.

Pada awal kegiatan beberapa anggota kelompok yakni SSP, RA, dan FR belum menunjukan sikap dan 
perilaku yang diharapkan oleh konselor. Akan tetapi dengan dorongan yang terus diberikan oleh konselor dan anggota kelompok lainnya membuat mereka semakin aktif menunjukan peranannya di dalam kelompok. Bahkan FR yang di kelas pada saat mata pelajarn diberikan bersikap pasif, takut berbicara, penyendiri dan tidak mempunyai teman menjadi aktif di kelas, berani bertanya kepada guru mata pelajaran, dan sudah berani berbaur bersama teman-temannya. Informasi ini di dapatkan dari teman-teman yang sekelas dengan FR di kelas dan guru mata pelajaran.

Tabel 4.7 Perolehan Skor Total Evaluasi Awal dan Evaluasi Akhir Tingkat Sopan santun Peserta didik

\begin{tabular}{|c|c|c|c|c|c|c|}
\hline No. & Nama & Pretest & Kat. & Posttest & Kat. & Perubahan \\
\hline \multirow[t]{2}{*}{1} & KA & 120 & $\mathrm{~T}$ & 155 & $\mathrm{~T}$ & 35 \\
\hline & & $63 \%$ & & $81 \%$ & & $18 \%$ \\
\hline \multirow[t]{2}{*}{2} & RA & 86 & $\mathrm{R}$ & 138 & $\mathrm{~T}$ & 52 \\
\hline & & $45 \%$ & & $72 \%$ & & $27 \%$ \\
\hline \multirow[t]{2}{*}{3} & SSP & 75 & SR & 111 & $\mathrm{R}$ & 36 \\
\hline & & $39 \%$ & & $58 \%$ & & $19 \%$ \\
\hline \multirow[t]{2}{*}{4} & FR & 85 & $\mathrm{R}$ & 130 & $\mathrm{~T}$ & 45 \\
\hline & & $44 \%$ & & $68 \%$ & & $23 \%$ \\
\hline \multirow[t]{2}{*}{5} & IF & 90 & $\mathrm{R}$ & 133 & $\mathrm{~T}$ & 43 \\
\hline & & $47 \%$ & & $69 \%$ & & $22 \%$ \\
\hline \multirow[t]{2}{*}{6} & $\mathrm{~S}$ & 87 & $\mathrm{R}$ & 129 & $\mathrm{~T}$ & 42 \\
\hline & & $45 \%$ & & $67 \%$ & & $22 \%$ \\
\hline \multirow[t]{2}{*}{7} & PN & 114 & $\mathrm{R}$ & 138 & $\mathrm{~T}$ & 24 \\
\hline & & $59 \%$ & & $72 \%$ & & $13 \%$ \\
\hline \multirow[t]{2}{*}{8} & ASA & 91 & $\mathrm{R}$ & 129 & $\mathrm{R}$ & 38 \\
\hline & & $47 \%$ & & $67 \%$ & & $20 \%$ \\
\hline \multirow{2}{*}{\multicolumn{2}{|c|}{$\begin{array}{l}\text { RATA- } \\
\text { RATA }\end{array}$}} & 93,5 & $\mathrm{R}$ & 132,875 & $\mathrm{~T}$ & 39,375 \\
\hline & & $49 \%$ & & $69 \%$ & & $21 \%$ \\
\hline
\end{tabular}

Paparan di atas memberikan gambaran jika peningkatan sopan santun peserta didik tidak hanya terjadi pada saat pelaksanaan layanan bimbingan kelompok berbasis nilai budaya belom bahadat, yang diungkap melalui laiseg dan skala sopan santun. Namun demikian peningkatan tersebut juga tampak dari sikap dan perilaku yang ditampilkan anggota kelompok dalam kesehariannya yang sudah "diwarnai" oleh nilai budaya belom bahadat.

\subsection{Uji Hipotesis dengan Tes Wilcoxon}

Uji keefektifan model layanan bimbingan kelompok berbasis nilai budaya belom bahadat untuk meningkatkan sikap sopan santun peserta didik dianalisis dengan statistik non-parametrik melalui uji Wilcoxon. Berikut ini adalah hasil uji efektifitas model yang dikembangkan pada perolehan skor total sikap sopan santun:

Tabel. 4. 8 Wilcoxon Signed Ranks Test Ranks

\begin{tabular}{|l|l|r|r|r|}
\hline & & $\mathrm{N}$ & $\begin{array}{r}\text { Mean } \\
\text { Rank }\end{array}$ & $\begin{array}{c}\text { Sum of } \\
\text { Ranks }\end{array}$ \\
\hline \multirow{3}{*}{$\begin{array}{l}\text { Prepost } \\
\text { Pretest }\end{array}$} & Negative Ranks & $0^{\mathrm{a}}$ & .00 & .00 \\
\cline { 2 - 5 } & Positive Ranks & $8^{\mathrm{b}}$ & 4.50 & 36.00 \\
\cline { 2 - 5 } & Ties & $0^{\mathrm{c}}$ & & \\
\cline { 2 - 6 } & Total & 8 & & \\
\hline
\end{tabular}

Dipublikasikan Oleh :

UPT Publikasi dan Pengelolaan Jurnal

Universitas Islam Kalimantan Muhammad Arsyad Al-Banjari Banjarmasin 
Berdasarkan tabel 4.8 pada nilai positive rank menunjukkan angka 8 yang bisa disimpulkan bahwa 8 orang anggota kelompok yang telah mengikuti kegiatan bimbingan kelompok berbasis nilai budaya belom bahadat mengalami peningkatan sikap sopan santun. Mean Rank atau rata-rata peningkatan menunjukkan angka 4,50 dan sum of rank atau jumlahnya menunjukkan angka 36.

Tabel. 4.9 Hasil Uji Wilcoxon

\begin{tabular}{|l|r|}
\hline & \multicolumn{2}{|c|}{ Prepost - Pretest } \\
\hline$Z$ & $-2.521^{\mathrm{a}}$ \\
\hline Asymp. Sig. (2-tailed) & .012 \\
\hline
\end{tabular}

a. Based on negative ranks.

b. Wilcoxon Signed Ranks Test

Berdasarkan Tabel 4.9 menunjukkan bahwa asymp sebesar 0,012<0,05 maka Ho (Hipotesis Nol) di tolak dan $\mathrm{Ha}$ (Hipotesis Alternatif) di terima sehingga dapat disimpulkan bahwa model bimbingan kelompok berbasis nilai budaya belom bahadat terbukti efektif untuk meningkatkan sikap sopan santun peserta didik kelas X di MAN Kota Palangka Raya.

\section{Pembahasan Penelitian}

Berdasarkan hasil analisis proses kegiatan model bimbingan kelompok berbasis nilai budaya belom bahadat serta hasil yang telah dicapai oleh anggota kelompok membuktikan bahwa bimbingan kelompok berbasis nilai budaya belom bahadat efektif untuk mmeningkatkan sikap sopan santun peserta didik MAN Kota Palangka Raya. Indikasi keberhasilan dilihat dari peran yang dimiliki oleh pemimpin kelompok dan anggota kelompok pada setiap tahapan. Sedangkan untuk efektifitas layanan bimbingan kelompok dapat dibuktikan dari hasil skala sikap sopan santun yang menunjukkan adanya peningkatan hasil akhir pada skor total.

Bimbingan kelompok merupakan sarana yang bisa diakses oleh siswa untuk mendapatkan layanan dalam suasana kelompok yang dinamis. Kebutuhan akan bimbingan kelompok tampak semakin jelas mana kala para siswa mengalami kesulitan dalam bergaul atau mengaktualisasikan dirinya pada lingkungan sosial. Faktor-faktor yang menghambat tugas-tugas perkembangan siswa di bidang sosial diharapkan menjadi pekerjaan konselor untuk mencari jalan keluar agar para siswa dapat menikmati kehidupan sosial yang layak. Solusi yang dimungkinkan untuk membantu siswa memecahkan masalah sosiologis adalah dengan memberikan layanan bimbingan kelompok yang berlandaskan pada pedoman beretika dalam masyarakat. Hurlock (2009: 257) menyatakan bahwa "perkembangan individu tidak terlepas atau dipengaruhi oleh budaya dimana individu itu berada". Peneliti berasumsi bahwa perkembangan sopan santun adalah masalah yang tidak terlepas dari etika dan budaya dalam berkelompok. Layanan bimbingan kelompok yang Dipublikasikan Oleh : UPT Publikasi dan Pengelolaan Jurnal

Universitas Islam Kalimantan Muhammad Arsyad Al-Banjari Banjarmasin dilaksanakan di MAN Kota Palangka Raya belum menggunakan keragaman nilai-nilai budaya yang ada pada anggota kelompok sehingga solusinya adalah dengan mengangkat suatu tema yang kaya akan nilainilai sosial dan budaya. Untuk membantu para konselor, peneliti akan melakukan penelitian guna menemukan suatu model yang dapat memberikan formula untuk meningkatkan sopan santun.

Masyarakat di Palangka Raya memiliki pedoman yang dimaksud terangkum dalam nilai budaya belom bahadat yang seharusnya dimiliki oleh setiap individu sehingga untuk membantu siswa terkait masalah sosial yang dihadapinya, nilai budaya belom bahadat dapat diinternalisasikan ke dalam layanan bimbingan kelompok. Bimbingan kelompok berbasis nilai budaya belom bahadat dimaksudkan sebagai suatu proses pemberian bantuan kepada siswa melalui suasana kelompok dengan berlandaskan pada nilai sosial budaya yang terdapat dalam nilai budaya belom bahadat. Adapun nilai-nilai yang dimaksud adalah takwa kepada tuhan, persamaan derajat, tenggang rasa, tidak semena-mena, menjunjung tinggi kemanusiaan, persatuan dan kesatuan, rela berkorban, cinta tanah air, musyawarah dan mufakat, rasa kekeluargaan, nurani yang luhur, menjunjung tinggi kebenaran, bertanggung jawab, menjunjung tinggi peri keadilan, gotong royong, menjaga keseimbangan hak dan kewajiban, menghormati hak-hak orang lain, sifat suka bekerja keras, menghargai karya orang lain, sifat keteladanan, semangat pengasih, ramah tamah, rasa saling hormat, sifat keterampilan diujung jari dan diunjung lidah, menjaga keseimbangan lingkungan dan lain-lain (Ilon, 1992).

\section{PENUTUP}

Bimbingan kelompok dilaksanakan hanya pada saat jam pelajaran kosong dan jumlah anggota kelompok terlalu banyak yaitu 1 (satu) kelas atau lebih dari 12 orang identik dengan bimbingan klasikal. Layanan diberikan secara insidental, artinya konselor hanya melaksanakan bimbingan kelompok ketika masalah itu sudah muncul pada peserta didik. Materi bimbingan kelompok di MAN Kota Palangka Raya 
yang diberikan hanya mengulang dari tahun-tahun sebelumnya yaitu materi tentang kedisplinan dan tata tertib sehingga cenderung monoton dan kurang variatif.

Pembahasan materi bimbingan kelompok yang berkenaan dengan Sopan Santun tidak pernah diberikan dan nilai budaya lokal belum di berdayakan dalam pelaksanaan bimbingan kelompok di MAN Kota Palangka Raya Beberapa peserta didik kurang menunjukkan sikap sopan santun kepada gurunya ataupun dengan sesama peserta didik. Perilaku yang ditunjukkan seperti tidak bertegur sapa dengan guru ketika berpas-pasan di lingkungan sekolah, tidak mengucapkan salam ketika masuk ke kelas, mengolok-olok sesama peserta didik,dan tidak menghargai pendapat sesama peserta didik. Peneliti menyimpulkan hal itu bisa terjadi karena kurangnya kurangnya pemahaman sikap sopan santun yang ada di peserta didik terlihat dari hasil wawancara kepada peserta didik yang menyatakan bahwa tidak menyapa karena mereka tidak mengenal gurunya dan guru tersebut tidak pernah mengajar dikelas mereka. Mereka hanya menegur guru yang pernah mengajar saja karena kenal.

Model bimbingan kelompok berbasis nilai budaya belom bahadat secara efektif dapat meningkatkan Sopan Santun. Simpulan ini di dasarkan pada hasil skala Sopan Santun, diperoleh hasil adanya peningkatan tingkat skala Sopan Santun dari sebelum dan sesudah mengikuti kegiatan bimbingan kelompok berbasis nilai budaya belom bahadat.

Konselor hendaknya meningkatkan kompetensinya dalam melaksanakan bimbingan kelompok sehingga layanan yang diberikan dapat optimal dalam mengatasi masalah yang terjadi. Jika masalah tersebut berkaitan dengan kehidupan sosial dan budaya seperti Sopan Santun maka konselor dapat menyisipkan nilai kearifan lokal yang kental dengan nilai sosial-budaya ke dalam bimbingan kelompok.
Oleh karena itu perlu melakukan need assesment terlebih dahulu sebelum memberikan layanan.

Model bimbingan kelompok berbasis nilai budaya belom bahadat dapat dijadikan sebagai salah satu pilihan oleh konselor sebagai upaya untuk memberi bantuan bagi peserta didik khususnya yang berkaitan dengan Sopan Santun.

\section{REFERENSI}

Arikunto, Suharsimi (2010). Prosedur Penelitian (suatu pendekatan Praktik (Edisi Revisi 2010)). Yogyakarta: Rineka Cipta

Hurlock, E. B. (2009). Psikologi Perkembangan. Jakarta: Erlangga.

Ilon Y Nathan (1992) Ilustrasi dan Perwujudan lambang batang garing dan Dandang Tingang. Kalimantan tengah Surabaya: Jurusan Sistem Informasi, Fakultas Teknik Informatika, ITS.

Narbuko C. Dan Ahmadi A. (2013) Metodologi Penelitian. Jakarta: PT Bumi Aksara

Madrosid. (Juni 2017). "Anggota DPRD Prihatin Siswa-Pukul-Guru Diakses dari: http// http://pontianak.tribunnews.com

Pemerintah Kalimantan Tengah. (2008).Peraturan Daerah Kalimantan Tengah No. 16 Tahun 2008 Tentang Kelembagaan Adat Dayak di Kalimantan Tengah. Peraturan Daerah Elektronik.

Sugiyono. (2013). Metode Penelitian Kuantitatif, Kualitatif dan R\&D. Bandung: C.V Alfabeta

Sukardi, D.K. (2008). Pengantar Pelaksanaan Program Bimbingan dan Konseling di Sekolah. Jakarta: Rineka Cipta.

Tomahayu,(2014): kajian teoretis dan hipotesis dan pengertian perilaku sopan santun [Online]. Di akses dari http://lib.unnes.ac.id/21159/1/1301411001s.pdf [30 agustus 2016] 